\title{
ENFORCING CONSTITUTIONAL CONVENTIONS ${ }^{\dagger}$
}

\author{
Farrah Ahmed, Melbourne Law School, University of Melbourne \\ Richard Albert, The University of Texas School of Law \\ Adam Perry, University of Oxford, Faculty of Law
}

In an earlier Article, we disproved the three claims central to the dominant view in the study of constitutional conventions: that there is a shared "Commonwealth approach" to constitutional conventions; that Commonwealth courts will recognize and employ conventions but never enforce them; and that conventions are sharply distinguishable from rules of law. We drew from Canada, India and the United Kingdom to demonstrate that Commonwealth courts have recognized, employed and indeed also enforced conventions. In this Article, we turn from the descriptive to the normative, arguing, again in contrast with the dominant view, that Commonwealth courts sometimes should enforce conventions. We argue that courts should act as executors of the will and judgment of constitutional actors, and limit themselves to enforcing only power-shifting conventions: conventions which transfer power from those who have legal power to those who can legitimately wield it. In playing this role, judges uphold the legitimate allocation of power-legitimate, not according to judges, but according to constitutional actors themselves.

\section{Introduction}

In an earlier Article, we disproved three foundational assumptions in the study of constitutional conventions that there is a shared "Commonwealth approach" to constitutional conventions; that Commonwealth courts will recognize and employ conventions but never enforce them; and that conventions are sharply distinguishable

\footnotetext{
${ }^{\dagger}$ For comments on an earlier draft, we are grateful to participants in the Workshop on Constitutional Boundaries held in August 2017 with the generous support of the Allen Myers Oxford-MLS Research Partnership, to Melbourne Law School for hosting Richard Albert and Adam Perry as Visiting Scholars to collaborate with Farrah Ahmed, and to the International Journal of Constitutional Law and their anonymous reviewers for helpful suggestions.
} 
from rules of law. 'We uncovered substantial variation among Commonwealth courts in their treatment of conventions: British courts only recognize and employ conventions; Canadian courts recognize, employ and non-legally enforce conventions; while Indian courts recognize, employ, non-legally enforce and legally enforce conventions. ${ }^{2}$ This progressively more fulsome judicial engagement with conventions belies the dominant but mistaken view that Commonwealth courts take a similar posture on conventions, and that Commonwealth courts never enforce conventions. ${ }^{3}$ In addition, by drawing on Indian case law, we showed that conventions have sometimes crystallized into law-a discovery of one of the 'holy grails' of public law. ${ }^{4}$

Our descriptive inquiry into whether Commonwealth courts ever do enforce conventions - they do, and not uncommonly-left open the normative question whether Commonwealth courts ever should enforce them. In this Article, we argue that judges are sometimes justified in enforcing constitutional conventions-a position that once again puts us at odds with the dominant view in the study of constitutional conventions. We think, however, that we stand on firm ground in taking the view that there are limited circumstances in which courts should engage in the legal enforcement of constitutional conventions. Our objective here is to draw on judicial and political practice in Commonwealth countries to develop a set of prescriptions for when and how courts should enforce conventions.

In Part II, we draw on our earlier Article, and briefly review the main ways that courts can engage with conventions, focusing on enforcement.

In Part III, we evaluate the four roles we have observed courts take when faced with a claim involving a convention. Courts can, we will show, quarantine themselves from questions concerning constitutional conventions. They may alternatively act as bystanders or serve as advisors to political actors in the face of conventions. Finally, courts which see themselves as guardians of the constitution would take an active role when confronted with question of law involving a constitutional convention. In our view, these four roles are inadequately justified.

In Part IV, we argue that courts should take a different role, that of an executor. An executor court, in brief, acts as executor of the will and

' Farrah Ahmed, Richard Albert \& Adam Perry, Judging Constitutional Conventions,

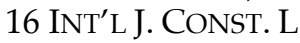
(2018).

Id . at

${ }^{3}$ Id. at

' N.W. Barber, Law and Constitutional Conventions, 125 L. Q. REV. 294, 302 (2009). 
judgment of constitutional actors, and limits itself to enforcing only power-shifting conventions, which transfer power from those who have legal power, to those who can legitimately wield it. In playing this role, judges uphold the legitimate allocation of powerlegitimate, not according to judges, but according to constitutional actors themselves-and they give effect to the legitimate expectations that constitutional actors have about who ought to wield power and how.

In Part $\mathrm{V}$, we demonstrate just how courts would fulfill this executor role when confronted with a constitutional convention. Drawing from a current instance of a convention in the Canadian Constitution, we construct a scenario to demonstrate that in some cases courts are justified in enforcing conventions-a sharp rejection of the dominant view that courts cannot and should not enforce conventions. We offer concluding thoughts in Part VI.

\section{MODES OF ENGAGEMENT}

In this preliminary Part, we review the main ways in which judges might engage with constitutional conventions.

The most fundamental way for a judge to engage with a convention is to recognize its existence or scope. Recognition is a fact-finding activity. If the existence or scope of the convention is uncontroversial, recognition might take the form of judicial notice. If on the other hand the convention is controversial, then there is a disputed question of fact. The judge will consider the relevant evidence and reach a determination about whether there is a convention and what it requires. Why would a judge inquire into a convention's existence or scope? It may simply be that the judge has been asked to resolve this factual question for the parties. Once the fact-finding process is over, the purpose of engaging with the convention is fulfilled.

Alternately, and more commonly, a judge might inquire into a convention's existence or scope because a legal issue turns on the matter. Recognizing the convention becomes a first step to using or employing the convention as a premise in an act of legal reasoning. Judges might, for example, draw on a convention to help interpret a provision of a statute or codified constitution, or to help determine whether a statutory provision applies to a case. ${ }^{5}$

Most importantly for our purposes, a judge can engage with a convention by enforcing it. The enforcement of a rule is an act which

${ }^{5}$ For discussion, see Peter W. Hogg, Constitutional Law of Canada 1-23 (5th ed. 2007). 
responds to a violation or would-be violation of the rule, and which prevents the rule from being violated or violated with impunity. Enforcing a rule means ensuring it is honored, if not through obedience, then at least by holding the violator to account. Here are two common ways of enforcing legal rules, which in principle could be extended to conventions:

- Imposition of further duties. If you break a law against speeding, the law's "Plan A" for responding will be to impose additional duties, such as a duty to pay a fine. Conventions could be enforced in the same way. For example, if Queen Elizabeth II refused to appoint as Prime Minister the person who heads a government capable of commanding the confidence of the House of Commons, then a judge might legally obligate her to do so.

- Harsh treatment. If you fail to live up to the additional duties the law imposes on you, the law typically resorts to "Plan B", which is to authorize or mandate harsh treatment towards you. If you do not pay speeding fines, for example, you might expect your driving license to be suspended. Harsh treatment could be the law's backup plan for enforcing constitutional conventions. For example, judges could require or specifically permit constitutional actors to punish convention-breakers.

Although it is possible for conventions to be judicially enforced via further duties or harsh treatment, we know of no actual examples of conventions being judicially enforced in these ways.

Two other forms of judicial enforcement are of greater practical importance:

- Declaration. Rules can be enforced by declaring that a person's conduct violates or would violate a rule. Once a light is shone on her conduct in this way, the person may take it upon herself to either correct her behavior or to make amends. For a declaration to qualify as a form of enforcement, two conditions must be met: (i) the violator or would-be violator must be committed to living up to her duties under the rule, and (ii) the person or body making the declaration must be regarded as an authority on what the rule requires. If constitutional actors are committed to living up to their constitutional duties, and judges are regarded as authorities on what the constitution requires, then a judicial declaration that a convention has been violated would be a form of judicial enforcement.

- Nullification. By nullifying an act contrary to a rule, or holding the act invalid, a judge can prevent the rule from being violated 
in the first place. Nullification is the usual way in which legally entrenched constitutional rules are enforced in Canada and India. In principle, a judge could enforce a convention by holding acts contrary to the convention invalid.

Enforcement through declaration and nullification already occurs in Canada and India. In the rest of this Article, when we talk of enforcement, it is enforcement through declaration and nullification that we have in mind.

\section{FOUR ROLES FOR COURTS}

In this Part, we construct and evaluate four ideal types of possible roles courts might play when confronted with a dispute involving a constitutional convention. The starkest option at one end of the spectrum is to quarantine courts from all questions related to constitutional conventions. On the other end, the court plays the role of guardian of the constitution, enforcing all forms of conventions that arise in the course of adjudication. Between both ends of this spectrum, the court may be either a bystander or an advisor when it comes to the existence, employment or enforcement of conventions. In our view, none of these four roles-the court quarantined or as bystander, adviser, or guardian-reflects the optimal judicial function where conventions are at play. We therefore construct a fifth role a court might play when faced with a dispute involving a constitutional convention: the executor court.

\section{A. Quarantined Courts}

When a court is quarantined, it must deal only with law, not conventions. Judges must not recognize, employ, and certainly not enforce, conventions. They might characterize this as either a constitutional or prudential issue of justiciability, as in the United States, where the political question doctrine counsels courts to take a position of non-engagement with constitutional conventions that amount to political questions. ${ }^{6}$

\footnotetext{
- Alexander Bickel famously grouped this doctrine with his list of passive virtues open to courts where they are faced with questions that straddle the boundary separating law from politics. AlEXANDER M. BICKEL, THE LEAST DANGEROUS BRANCH: THE SupREME COURT AT THE BAR OF POlitics 183-97 (2d ed. 1986). The political question doctrine forbids engagement with these types of conventions whether it amounts to recognition, employment and enforcement. See James G. Wilson, American Constitutional Conventions: The Judicially Unenforceable Rules that
} 
There are perils in judicial engagement with constitutional conventions. One peril is that judges might make incorrect judgments about the existence, scope or content of conventions due to their lack of expertise or "institutional capacity": Adam Dodek writes that conventions "do not lend themselves to the definitive answers that courts are good at providing in binary litigation." " He offers the example of dissenting judges in the well-known Patriation References (discussed in our earlier article in this journal ${ }^{\prime}$ ) incorrectly identifying the practice that "after a general election the Governor General will call upon the leader of the party with the greatest number of seats to form a government" as a convention. ${ }^{10}$

Recognizing that errors about conventions in legal cases can have serious consequences, judges might self-quarantine out of fear of making a mistake, or out of concern for preserving a court's perceived authority. Doubt about judicial ability to make correct decisions on constitutional conventions might prompt doubts about judicial ability to make decisions on constitutional law. Judicial engagement with conventions might also create the impression of political partisanship and interference in the political sphere. Given these perils, selfquarantining is a natural role for a cautious court.

But there are reasons to doubt that quarantining is either a practical or justifiable role for courts. As we argued in our earlier article, judges routinely employ conventions in statutory interpretation, and in deciding whether and how to develop the common law." If judges did not take conventions into account when interpreting statutory text, their interpretations would be less accurate. If they refused to consider conventions even when necessary to apply a legal rule, they could not make decisions in important legal cases. The common law would be poorer, and developed without regard to relevant considerations, if judges ignored conventions in shaping it. There is an additional problem: if judges did not recognize and employ conventions, they would risk over-regulation, for instance by creating legal rules that overlap with constitutional conventions.

Combine with Judicial Doctrine and Public Opinion to Regulate Political Behavior, 40 BUFFALO L. REV. 645 (1992).

'Adam M. Dodek, Courting Constitutional Danger: Constitutional Conventions and the Legacy of the Patriation Reference, 54 SuP. CT. L. REV. (2d) 117, 134 (2011).

- Reference re: Resolution to Amend the Constitution, 1 S.C.R. 753, 904-05 (1981) ("Patriation Reference").

- Ahmed, Albert and Perry, supra note 1.

" Patriation Reference, supra, note 8 . Dodek uses the Jennings test that the judges themselves endorsed. Dodek, supra note 7, at 134-38.

"Ahmed, Albert and Perry, supra note 1. 
It is a mark of the impracticality of self-quarantining that no court can with any reliability assume this role. Even in the United Stateswhere the political question doctrine can prevent judicial engagement with conventions-courts have employed conventions in the resolution of decidedly legal disputes. For instance, the Supreme Court recently employed a constitutional convention as an aide to interpret a statute..$^{12}$

Moreover, the perils of judicial engagement with conventions are often overstated. Judges may not understand party politics, but as Peter Oliver notes "any judge who wishes to understand a constitution in the British tradition must understand constitutional conventions. ${ }^{113}$ Courts are used to thinking about constitutions, and it is impossible to understand a constitution in the Commonwealth tradition without an appreciation of its conventions. Moreover, courts are used to identifying and applying non-legal rules that are like conventions: rules of lex mercatoria, rules of professional and sporting bodies, rules of clubs, policies of government departments, universities and other bodies. Courts have devised methods of gathering and weighing evidence about these rules, including the appointment of expert witnesses. These methods would stand them in good stead when engaging with constitutional conventions.

\section{B. Bystander Courts}

A second judicial role, of courts as bystanders, responds to the impracticality of quarantining. Bystander courts believe that political rules should remain a matter for political actors, and that courts should concern themselves only with legal questions. They acknowledge that deciding legal questions sometimes requires judicial recognition and employment of conventions, and they are willing to engage with conventions to that extent - but no further. In particular, they are unwilling to declare or legally enforce conventions.

Recently, the UK Supreme Court self-consciously adopted the role of bystander in Miller v. Secretary of State for Exiting the European

"See Free Enterprise Fund v. Public Co. Accounting Oversight Board (PCAOB), 561 U.S. 477 (2010).

${ }^{13}$ Peter C. Oliver, Constitutional Conventions in the Canadian Courts at: https: / / ukconstitutionallaw.org/2011/11/04/ peter-c-oliver-constitutionalconventions-in-the-canadian-courts (last visited March 27, 2018). 
Union. ${ }^{14}$ The Court was asked to declare that it would be unconstitutional, by virtue of a convention, for Parliament to enact legislation paving the way for the UK to exit the European Union without first obtaining the consent of Scotland, Wales, and Northern Ireland. The court flatly refused. Judges are "neither the parents nor the guardians of political conventions; they are merely observers" ${ }^{15}$ Although they "can recognise the operation of a political convention in the context of deciding a legal question" ${ }_{16}$ they cannot "give legal rulings on [a convention's] operation or scope, because those matters are determined within the political world." ${ }_{17}$

Bystander courts are driven by the same fears that drive quarantined courts: that they will be seen as politically partisan, power-hungry bodies that interfere with and encroach on the powers of democratic institutions. But what if restricting courts to this bystander role denies a useful service to political actors, and to the political constitution? What if political actors request that judges offer advice on conventions, even when there is no legal question at stake?

\section{Advisor Courts}

These questions suggest a third role a court might play when faced with a constitutional convention. Judges might regard themselves as properly suited to advise political actors, or perhaps even citizens, on the requirements of the constitution, including conventional requirements.

Return to the Patriation Reference..$^{18}$ It was in fact an advisory opinion requested by political actors. The Canadian federal government has the power to refer questions of law or fact to the Supreme Court, ${ }^{19}$ but the Court has the "discretion to refuse to answer such questions" if they are not justiciable. ${ }^{20}$ The question of justiciability here turns on prudential rather than constitutional considerations. As Peter Oliver suggests, a question is likely to be considered non-justiciable where it implicates "the courts' sense of its proper role vis-à-vis other

\footnotetext{
"R. (Miller) v. Secretary of State for Exiting the European Union, U.K.S.C. 5 (2017) ("Miller").

${ }^{15} \mathrm{Id}$. at 146.

${ }^{16}$ Id.

"Id.

${ }^{18}$ Patriation Reference, supra note 8.

19 Supreme Court Act, R.S.C., 1985, c. S-26, at s. 53.

${ }^{20}$ Patriation Reference, supra note 8 , at 768 .
} 
institutions." ${ }_{21}$ That the Court issued its advisory opinion in the Patriation Reference raises a question: why did the Court see its "proper role" here as requiring a ruling on the existence of conventions, rather than requiring it to stand aside as a bystander court would have done?

The main reason was that the question posed to the Court was "constitutional in character." ${ }_{22}$ Even though the question was "not confined to an issue of pure legality," it was concerned "with a fundamental issue of constitutionality and legality." ${ }^{23}$ The Court saw itself as having a responsibility to engage with constitutional issues, even where they were not strictly legal ones. As the Court understood its role, it should serve, when asked, as adviser on what the constitution demands, including its non-legal rules as well.

Why should courts adopt this role, instead of leaving it to political actors to figure out for themselves what constitutional conventions require? The Supreme Court did not answer this question, but we can sketch an answer it might have given.

Where conventions are properly understood-or at least where there is a settled view on their content-conventions can bring predictability to interactions among political actors: they can structure and limit the exercise of discretionary power, ${ }^{24}$ and they can coordinate conduct. ${ }^{25}$ Conventions can serve these valuable functions, but only if there is clarity on whether they exist and what they require. Unfortunately, clarity and certainty are often absent. Even when political actors are motivated to follow conventions, they may not know what the relevant conventions are, and where they begin and end. Individual political actors may think they know the answers to these questions, but when their interpretations differ, there will be disagreement and potentially stalemate.

Judges can potentially help political actors resolve disagreement and clarify uncertainty by providing guidance as to which conventions exist and how far they extend. To serve its purposes, this guidance must be treated as authoritative by political actors-as settling, for practical purposes, the scope and application of conventions. One might well ask why would political actors treat judges as authorities on these matters? One reason is judicial expertise in finding and evaluating precedents, and understanding how they fit together in the legal system. But the more important reason is judicial

${ }^{2}$ OLIVER, supra note 13.

"Patriation Reference, supra note 8, at 884 (quoting Freedman C.J.M.).

${ }^{23} \mathrm{Id}$.

${ }^{24}$ See Joseph Jaconelli, The Proper Roles for Constitutional Conventions, 38 DubLIN U. L.J. 363 (2015).

${ }^{25}$ Adrian Vermeule, Conventions in Court, 38 Dublin U. L.J. 283, 302 (2015). 
independence. Judges do not usually have a direct stake in the outcome of political disputes. Even if they do, they are expected and trained to set aside any political views that might raise a conflict of interest. Insofar as they are relatively neutral arbiters in disagreements about conventions, judges might therefore be seen as an attractive third party to which political actors can turn.

On this account, judges are well-positioned, by virtue of their expertise and independence, to serve as guides to the requirements of the constitution. And they are justified in serving in this capacity, given the desirability of stability and certainty in the operation of the constitution. This, at least, is the ideal type of courts as advisors.

The Canadian Supreme Court justified its role as an advisor, in part, by denying that it was enforcing a convention. The advisor role thus appears to strike an attractive middle ground between the court as bystander and the court as enforcer of conventions. The attractiveness of this role, then, depends on there being an important difference between declaring and enforcing a convention.

But where political actors take a court's declaration as settling what they ought to do, the declaration prevents the rule from being violated or violated with impunity. This amounts to a form of enforcement-a point made in the scholarly commentary on the Patriation Reference..$^{20}$ Advisor courts therefore find themselves in a bind. If political actors take a court's declarations on conventions as authoritative, this would amount to judicial enforcement of conventions, which is largely discomfiting in the Commonwealth. And if political actors do not take a court's declarations on conventions as authoritative, then the whole point of judges offering advice-to end disagreement and promote stability and certainty in the operation of the conventional parts of the constitution-is lost. Advisor courts are thus either objectionable or pointless.

\section{Guardian Courts}

Given the inherent instability in the advisor role, courts need not necessarily retreat to playing the role of bystanders. They could

\footnotetext{
26 See, e.g., ANDREW HeARd, CANAdian CONSTitutional Conventions: The MARRIAGE OF LAW AND POLITICS 154 (1991); G. J. Brandt, Judicial Mediation of Political Disputes: The Patriation Reference, 20 U. W. ONTARIO L. REV. 101, 119-20 (1982); Fabien Gélinas and Léonid Sirota, Constitutional Conventions and Senate Reform, 5 REvUE QUÉBÉCOISE DE DROIT CONSTITUTIONNEL 107, 111 (2013).
} 
instead embrace their role as guardians of the constitution. ${ }^{27}$ This is not just mythology; we see courts around the world inhabiting the guardian role when they invalidate an exercise of executive or legislative power, or even invalidate constitutional amendments for violating the core commitments of the constitution. ${ }^{28}$ Courts therefore have come to see their role as protecting the constitution from what in their view amounts to damage or, worse yet, destruction by other branches. Nowhere have judges been more serious about this role than India. The Indian Supreme Court has even chided the Canadian Supreme Court for its reluctance to enforce conventions. In our earlier article in this journal ${ }^{29}$ we demonstrated how the Indian Supreme Court has given all constitutional conventions the force of law..$^{30}$

We think there are at least three objections to courts adopting this radical role. The first objection is that the functions of conventions often make judicial enforcement inappropriate. Intra-institutional conventions, for example, regulate the internal affairs of an institution of government. Examples include the Salisbury-Addison Convention, which regulates the internal business of the Westminster Parliament; the convention of cabinet solidarity, which regulates the internal business of the cabinet in Canada; or in India, the convention that a judge will resign rather than face parliamentary proceedings after a judicial committee has recommended removal. Were a court to enforce one of these intra-institutional conventions, it would run afoul of the important principle of comity, that is, the principle that each branch of government ought to let the other branches carry out their constitutional responsibilities without undue interference..$^{31}$ To enforce the convention of cabinet solidarity would, for example, make a court the arbiter of the executive's internal disputes, and fail to respect the executive's capacity to fulfil its role under the constitution.

Or consider accountability conventions, which make some institution or actor accountable to some other institution or actor: for instance, conventions of individual and ministerial responsibility, which make the government and its ministers accountable to our democratic

\footnotetext{
${ }^{27}$ THE FEDERALIST No. 78 (Alexander Hamilton) (describing judges' “duty as faithful guardians of the Constitution").

${ }_{28}$ For a comprehensive study of the rise and operation of the doctrine of unconstitutional constitutional amendment, see YANIV ROZNAI, UNCONSTITUTIONAL CONSTITUTIONAL AMENDMENTS: THE LIMITS OF AMENDMENT POWERS (2017).

${ }^{2}$ Ahmed, Albert and Perry, supra note 1.

${ }^{30}$ Supreme Court Advocates-on-Record Association v. Union of India, 4 S.C.C. 441, para. 455 (India) (1993) ("Second Judges Case").

"See, e.g., Michael Foley, ThE POlitics of THE BRitish CONSTITUtion 14 (1999); Robert A. Katzmann, The Underlying Concerns, in JUDGES AND LEGISLATURES: TOWARD INSTITUTIONAL COMITY 7, 14 (Robert A. Katzmann ed., 1988).
} 
representatives. For the conventions to succeed in that aim, political actors must be the ones to hold the government to account, by raising our concerns, rebuking failures, prosecuting grievances, and otherwise making public the government's shortcomings. If judges do these things instead, then it is judges, not our democratic representatives, who hold the government to account. Judicial enforcement of accountability conventions would frustrate their purpose. If all conventions are like intra-institutional and accountability conventions, then judges should not enforce conventions.

Even if this first objection can be overcome (and, as we will explain in Part IV, we believe it can be) there are two further objections to the guardian role. On closer inspection, the role does not offer any positive reason for judicially enforcing conventions. If the question is, "why, if at all, should judges enforce conventions?", the answer cannot be "because judges should enforce all rules of the constitution." That answer begs the question. The dispute is precisely about whether judges should enforce all rules of the constitution or merely those rules which are traditionally recognized as having legal status. Indeed, when the Indian Supreme Court enforced conventions, it is striking that the Court offered no clear reason for concluding that it ought to enforce them. ${ }^{32}$ It assumed, rather than justified, its role as constitutional guardian.

Our final objection is about the apparent novelty of judicial enforcement of conventions. No codified constitution gives courts the express or implied power to legally enforce conventions, so courts would have to arrogate that power to themselves. This is what the Indian Supreme Court did, but virtually no other court has done the same-and, it would seem, for good reason. Common law judges do not generally have the power to create new doctrines out of whole cloth; the common law is meant to develop incrementally, by extending existing law in new directions. Were judges suddenly to create a new legal rule requiring conformity with convention, judges would have acted not as guardians of the constitution but as creators of its rules-a role reserved for other constitutional actors. ${ }^{33}$

\footnotetext{
"See Second Judges Case, supra note 30; Supreme Court Advocates-on-Record Association v. Union of India, SCC OnLine SC 964 (2015) ("NJAC"); Madras Bar Association v. Union of India, AIR SC 1571 (2015); Consumer Education Research Society v. Union of India, 9 SCC 648 (2009).

${ }^{3}$ In extreme cases of this judicial conduct, one might take the view that courts exercise a constituent power in remaking the constitution. See, e.g., Timothy Endicott, Lord Reed's Dissent in Gina Miller's Case and the Principles of our Constitution, 8 UK SUP. CT. YB. 1, 16 (2017).
} 
In summary, the guardian model faces objections from all corners: the functions of conventions, the lack of a positive reason for judicial enforcement, and the novelty of the proposal. We do not think there is any way to salvage the guardian model. But it is in fact possible to identify a more limited role for the judicial enforcement of conventions that invites courts to do considerably more than sit as mere bystanders in the face of dispute about a constitutional convention.

\section{A NEW JUDICIAL ROLE: THE EXECUTOR COURT}

Let us begin with the objection to courts enforcing conventions based on the functions of conventions. We stressed that judges ought not to enforce either intra-institutional conventions or accountability conventions because of comity and to avoid frustrating the very purpose of the conventions. But not all conventions are of these two types. There are, in addition, power-shifting conventions: conventions which transfer power from those who have legal power to those who can legitimately wield it.

\section{A. Power-Shifting Conventions}

For example, in law, the British monarch can veto bills, deploy the armed forces, sack ministers, free prisoners, and abolish government departments, to give just a few examples. But the "cardinal convention" of the British Constitution says that the monarch must only act as her ministers advise. ${ }^{34}$ In law, the monarch looks like a tyrant; by virtue of a convention, de facto power is exercised by ministers. In India, the convention at issue in two of the most significant cases of conventions discussed in our earlier paper in detail - the Second Judges Case ${ }^{35}$ and the National Judicial Appointments Commission Case ("NJAC") ) $^{36}$ - is another good example of a powershifting convention: the Constitution gives the final say on judicial appointments to the executive, but a convention shifts de facto power over appointments to senior judges. In previous centuries, Commonwealth relations were regulated by a network of conventions, many of which shifted de facto decision-making authority away from Britain to colonies, territories, and dominions. Today the

34 Rodney Brazier, CONSTitutional Practice: THE FOUndations OF British GOVERNMENT 178 (1999).

${ }^{35}$ Supreme Court Advocates-on-Record Association v. Union of India, 4 S.C.C. 441, para. 455 (1993) (India)

${ }^{36}$ NJAC, supra note 32 . 
Sewel Convention serves a similar function: legally, Scotland does not have a veto over legislation which alters the devolution arrangements; practically, it does, by virtue of a convention. Similarly, the convention in the Patriation Reference shifted legitimate authority to request a major amendment to the Canadian Constitution away from the federal government alone to the provincial governments in tandem.

Power-shifting conventions do not regulate the internal workings of an institution, so their judicial enforcement would not threaten comity, as the enforcement of an intra-institutional convention would. On the contrary, by enforcing a power-shifting convention, judges would uphold, rather than disrupt, the constitutional allocation of power. Also, by enforcing a power-shifting convention, judges would not undermine the point of the convention, as they would by enforcing an accountability convention. The point of a power-shifting convention is for de facto authority to be exercised by some office or body to whom de jure authority has not been granted. To enforce the convention would not frustrate that purpose.

So much for the first objection. Is there any positive reason for judges to enforce power-shifting conventions? By enforcing powershifting conventions, judges would enforce the legitimate allocation of constitutional decision-making authority. It is not legitimate, for example, for the monarch to make important decisions contrary to ministerial advice. By enforcing the convention that the monarch must follow ministerial guidance, judges ensure that only those who can legitimately wield power do so. Upholding the legitimate allocation of power is, we think, a proper role for judges to play.

Some might worry about how much latitude we are giving to judges. Are we suggesting that judges should be able to decide who can legitimately wield power and who not, and then enforce their preferences, whatever the law might say? Not at all. Constitutional conventions are typically social rules, meaning they are grounded in a pattern of action and acceptance..$^{37}$ Over time, constitutional actors repeatedly act in some way, and it comes to be accepted that they ought to continue to act in that way-accepted, that is, by constitutional actors themselves. To accept that a constitutional actor ought to act in some way is to accept that doing so is legitimate. Thus,

${ }^{37}$ For this account of social rules, see H.L.A. HART, THE CONCEPT OF LAW 8-10, 55-57, 254-256 ( 3 d ed. 2012). For the view that constitutional conventions are social rules, see JEREMY WALDRON, THE LAW (1990); Joseph Jaconelli, The Nature of Constitutional Conventions, 19 LEG. STUD. 24 (1999). Not all constitutional conventions are social rules: see A. Perry and A. Tucker, Top-Down Constitutional Conventions, MODERN LAW REVIEW (forthcoming 2018). However, to be of practical importance, our argument only requires that many or most conventions are social rules. 
conventions reflect the judgment of constitutional actors that certain behavior is legitimate.

For power-shifting conventions, the story is the same. Powershifting conventions express constitutional actors' collective judgment that power is legitimately exercised, not by the person to whom the law allocates it, but by someone else-someone who is more accountable, say, or someone with better democratic credentials. When a constitutional actor breaks a power-shifting convention, the actor breaks a standard of the constitutional community. Her conduct is illegitimate by that community's own rules. It would be problematic for judges to enforce their own views of what they think is legitimate. But by enforcing power-shifting conventions, judges instead enforce what constitutional actors regard as the legitimate allocation of power.

\section{B. Enforcing Legitimate Expectations}

So far, we have offered a normative justification for judicial enforcement, and by limiting the argument to power-shifting conventions, we have neutralized the objection that the functions of conventions make them unsuitable for judicial enforcement. A final obstacle remains: the objection from novelty. To enforce powershifting conventions, it might seem that judges would have to fashion a new rule from scratch, which they arguably lack the power to do. We think there exists a ready response, which if it has been overlooked, is likely because it is found not in constitutional law, but in administrative law.

To enforce a constitutional convention is to enforce a non-legal rule, created by, and applicable to, public actors. In case after case, courts already do exactly this. They enforce non-legal rules created by public actors against those same actors. They do so under the doctrine of legitimate expectations. This is a relatively new doctrine, but it is now firmly established in the administrative law of Canada, India, and the United Kingdom (as well as in many other jurisdictions). ${ }^{38}$ As two of us have argued elsewhere, in essence, the doctrine says that if a public actor has made a norm and then deviates from that norm, then a court will provide a remedy, unless there is good reason not to. ${ }^{39}$

\footnotetext{
${ }^{3}$ See generally, MATTHEW GROVES AND GREG WEEKS (ED), LEGITIMATE EXPECTATIONS IN THE COMMON LAW WORLD (2017).

${ }^{3}$ See Farrah Ahmed \& Adam Perry, The Coherence of the Doctrine of Legitimate Expectations, 73 CAMBRIDGE L.J. 61, 78-79 (2014).
} 
Two points about the doctrine of legitimate expectations are crucial for our purposes. First, the norms which trigger the doctrine include social rules, a claim recently made by two of us, Farrah Ahmed and Adam Perry. ${ }^{40}$ Ahmed and Perry support that claim through a detailed examination of case law. Consider one of their examples: $R v$ Inland Revenue Commissioners, ex $p$ Unilever plc." The Inland Revenue had discretion to accept late claims for tax relief, and exercised that discretion in favour of Unilever on many occasions. Over 25 years, there eventually arose a well-established practice of Unilever submitting an estimate, followed later by its final calculation, and the Inland Revenue accepting its (late) final calculations. This was a 'scheme of close cooperation' ${ }^{42}$ which was "faithfully followed". ${ }^{43}$ The long interaction between Unilever and the Inland Revenue established a non-legal, social rule between the parties, one which required the Inland Revenue to accept Unilever's late returns. When one year, the Internal Revenue suddenly decided to enforce the time limit, Unilever was able to successfully challenge the decision. Given the rule which existed between the parties, the Internal Revenue was no longer free to exercise its discretion as it wished, at least not without notice. Thus, the law enforced the non-legal rule with which the Internal Revenue had bound itself.

To take another example, in $R v$ British Coal Cpn., ex $p$. Vardy the National Coal Board created a procedure to consult mining unions about the closure of collieries. Seven years later, the board ordered the closure of 10 collieries but refused to follow the consultation procedure. The unions successfully argued that the decision frustrated their legitimate expectation. The unions relied on the fact "that the [consultation] mechanism had been constantly used" ${ }^{\prime 5}$. Also, the Board had previously accepted that it was "clearly appropriate" ${ }^{46}$ to follow the consultation procedure, and that consultation was "in accordance with the understandings reached" ${ }^{\prime 7}$ with the unions. The judge said that by such statements the Board was "indicating to the [mining] unions its commitment to the continuation of the ... procedure" ${ }^{\prime \prime s}$,

${ }^{40}$ Ibid.

" $R v$ Inland Revenue Commissioners, ex p. Unilever plc STC 681 (1996) (CA).

${ }^{4}$ Ibid., at p. 696.

${ }^{4}$ Ibid.

"R v British Coal Cpn., ex p. Vardy I.C.R. 720 (1993) (Q.B.).

${ }^{45}$ Ibid., at p. 758 (Glidewell LJ).

t6 Ibid., at p. 763 (Hidden J).

" Ibid.

${ }^{4}$ Ibid., at p. 764 (Hidden J). 
which "entitled [them] to continue with the belief that the [Board's] attitude to the review procedure had not changed" ${ }^{\prime 9}$. Ahmed and Perry argue that cases like Unilever and Vardy are typical: in general, the practices that generate legitimate expectations are social rules. This matters, of course, because power-shifting conventions are typically social rules.

The second crucial point about the doctrine of legitimate expectations is that the norms which trigger the doctrine apply to a range of acts and actors. The doctrine is triggered by norms which apply to constitutional actors, such as ministers carrying out acts of a constitutional character, ${ }^{50}$ such as colonial governance..$^{51}$ It is triggered by norms which regulate the use of prerogative or "original" powers..$^{52}$ The doctrine also applies in disputes between different branches or levels of government. ${ }^{\text {s3 }}$ The range of the doctrine matters because power-shifting conventions apply to constitutional actors and acts, to interactions between constitutional actors or institutions, and typically to the use of prerogative or original powers.

\section{Enforcing Power-Shifting Conventions}

We can now bring the strands of this Part together. Under the doctrine of legitimate expectations, if a public body engages in a practice of acting in some way sufficient to generate a social rule, then the court will provide a remedy if that body breaches that rule, unless there is good reason to the contrary. Power-shifting conventions are social rules. Providing a remedy for the breach of a rule is a form of enforcement. The doctrine of legitimate expectations provides a legal foundation for enforcing these power-shifting conventions. We acknowledge that the doctrine has not so far been used in this way and would need to be extended. ${ }^{5 t}$ But to extend the existing doctrine to the

\footnotetext{
"2 Ibid.

${ }^{s 0}$ E.g. Agraira v Canada 2 SCR 559 (2013); R v. Home Secretary, ex $p$ Khan, 1 WLR 1337 (1984) (CA); M.P. Oil Extraction v. State of Madhya Pradesh 7 SCC 592 (1997).

${ }^{5} R$ (Bancoult) $v$. Secretary of State for Foreign and Commonwealth Affairs, UKHL 61 (2008) 1 AC 453 (2009).

"Council of Civil Service Unions v. Minister for the Civil Service, AC 374 (1985) (cited repeatedly with approval in Indian and Canadian courts); Black v. Canada (Prime Minister), CanLII 8537 (2001) (ON CA).

${ }^{s} R v$. Secretary for State for Transport exp Richmond Upon Thames LBC, 1 WLR 74 (1994) (QB); $R$ (Luton Borough Council $\mathcal{E}$ Nottingham City Council and others) v. Secretary of State for Education, EWHC 217 (2011).

st For example, it would have to expand to give greater substantive protection for legitimate expectations in Canadian administrative law.
} 
closely analogous context of constitutional conventions accords with the role of the common law judge as agent of incremental legal development. This extension of the doctrine has been anticipated by Trevor Allan who takes it for granted that constitutional conventions create legitimate expectations, arguing that "the wider constitutional canvas...is critical to the scope and application of legal doctrine". ${ }^{.55}$

Here, then, is the role we see for judges. By enforcing powershifting conventions, judges uphold the legitimate allocation of power-legitimate, not according to judges, but according to constitutional actors. In our vision, judges act as executors of the will and judgment of constitutional actors. Constitutional actors decide who can legitimately wield power; judges execute their decisions. To fulfill this role, judges need only do what they currently do in many other contexts when they enforce the social rules with which public actors bind themselves. Judges therefore have an executive role to play in giving effect to widely shared judgments of who can legitimately exercise power, and they can do so using doctrinal tools they already have available to them.

How, or by what means, should judges enforce power-shifting conventions? We doubt there is a general answer to this question. A number of factors will be important. One is the nature of the power. Suppose that Queen Elizabeth II appointed her butler as Chancellor of the Exchequer, contrary to the advice of her Prime Minister. This is not a legal power. Hence, its exercise cannot be invalidated, and nullification would not be a sensible judicial response. Second, comity favors the least intrusive remedy which is still effective, and thus another factor is the willingness of the actor who breached the convention to abide by the court's determination of its legal responsibilities. Suppose that the Queen would very likely conform her conduct to what a judge decided she legally ought to do. In that case, a declaration that appointing her butler is unlawful would be more appropriate than an order prohibiting her from doing so. A third factor is the existence of any legal restrictions on a court's power to enforce conventions in a particular way. For example, under the doctrine of parliamentary sovereignty, there is no law that Parliament lacks the legal power to create. Unlike in India, judges in the United Kingdom cannot therefore enforce the Sewel Convention by nullification, namely by invalidating a statute enacted contrary to the convention. British courts thus have two options. To legally enforce the convention, a court could declare that enacting the offending

s5 TRS AlLAN, CONSTITUTION AND CONSTITUTIONALISM 68-69 (2013). 
statute was unlawful, even though the statute itself is valid. ${ }^{56}$ Alternately, to enforce the convention through non-legal means, a court could declare that enacting the statute was unconstitutional even though it was not unlawful.

\section{EXECUTOR COURTS-AN ILLUSTRATION}

As an abstraction, the idea of courts upholding the legitimate allocation of decision-making authority is appealing. But its appeal may be further demonstrated by illustrating how it would work in practice.

\section{A. Disallowance and Reservation}

Return now to the Canadian Constitution. Our focus is two powers. The disallowance power authorizes the Governor in Council (in effect, the Government of Canada) to repeal a law passed by a provincial legislature; ${ }^{57}$ this power may be exercised within one year of the law coming into force. ${ }^{.5}$ The reservation power authorizes the Government of Canada to place a "hold" on a bill that is presented to the Lieutenant Governor for royal assent; ${ }^{59}$ the Government of Canada then has up to

\footnotetext{
${ }^{56}$ It can be unlawful to pass a statute without that statute being invalid, because it is possible to possess a power which it is unlawful to exercise. See H.L.A. Hart, Bentham on Powers, 81 YALE L.J. 799, 816 (1972).

${ }^{37}$ Constitution Act, 1867, 30 \& 31 Victoria, c. 3 (U.K.), pt. V, s. 90. The Queen in Council, in other words the Government of the United Kingdom, could once exercise a similar power in relation to laws passed by the Parliament of Canada. Id. at pt. IV, ss. 55-57.

${ }^{s} \mathrm{Id}$.

"The Governor in Council would either instruct the Governor General to in turn instruct the Lieutenant Governor to reserve the bill, or it would pass the instruction along directly.
} 
one year give further instructions to the Lieutenant Governor. ${ }^{\circ}$ Neither power has been used in the last 55 years."1

In 1938, the Supreme Court of Canada heard a reference on the validity of both powers. ${ }^{62}$ Four questions were referred to the Court after controversy around the disallowance of three Alberta laws. The relevant question for us was whether the disallowance and reservation powers remained "subsisting" powers and, if so, whether either was subject to any limitations or restrictions. ${ }^{63}$ In its unanimous advisory opinion, the Court confirmed that both powers were valid and therefore useable. " Two judges insisted that "we are not concerned with constitutional usage," adding that "we are concerned with questions of law which, we repeat, must be determined by reference to the enactments the British North America Acts of 1867 to 1930, the Statute of Westminster, and, it might be, to relevant statutes of the Parliament of Canada if there were any." ${ }_{55}$ Another concluded that both powers "remain[ ] in full vigour." "Still another described the disallowance power as "unrestricted" ${ }^{\circ}$ and the reservation power as subject to "no limitations or restrictions...." ${ }^{\circ}$ One judge took a more deferential view in explaining why the powers were still useable, insisting that their exercise were "matters upon which this Court is not constitutionally empowered to express an opinion... ." ${ }_{9}$ The most definitive statement about the continued viability of both powers was

\footnotetext{
${ }^{6}$ Constitution Act, 1867, Pt. V, s. 90. The Canadian reservation power appears also to allow the Lieutenant-Governor to exercise the power of reservation of her own volition, subject to further instructions from the Governor General, who is in turn instructed by the Government of Canada sitting as Governor in Council. The Constitution Act, 1867 also authorizes the government of the UK to reserve a bill that is presented to the Governor General for royal assent. The Government of the UK then has two years to consider whether to instruct the Governor General to give royal assent; the bill expires at the end of that period if no assent is given. $I d$. at $\mathrm{Pt}$. IV, ss. 55-57. Though they remain in the text of the Constitution Act, 1867, both of the UK powers have been formally repealed by the 1931 Statute of Westminster.

"See Bruce M. Hicks, The Crown's "Democratic" Reserve Powers, 44 J. CAN. STUD. 5, 15 (2010).

"Reference re: The Power of the Governor General in Council to Disallow Provincial Legislation and the Power of Reservation of a Lieutenant-Governor of a Province, S.C.R. 71 (1938) (Can.)

${ }^{6} \mathrm{Id}$.

${ }^{6} \mathrm{Id}$.

${ }^{6} \mathrm{Id}$. at 78 (The Chief Justice and Davis J.).

${ }^{\circ} \mathrm{Id}$. at 80 (Cannon J.).

${ }^{6}$ Id. at 86 (Crocket J.).

${ }^{\circ} \mathrm{Id}$. at 88 (Crocket J.).

${ }^{6} \mathrm{Id}$. at 95 (Kerwin J.).
} 
that "there is no room for serious argument" about their use because they "have not been repealed... ."

But that reference is 80 years old. Since then the political winds have reversed direction. Today the dominant and widespread judicial and scholarly consensus is that there has arisen a convention against the use of the reservation and disallowance powers. A leading scholar of constitutional conventions in Canada, Andrew Heard, observes that there is a "widely based consensus" that disallowance and reservation can no longer be used because "clear and broadly accepted conventions have arisen to nullify" them. ${ }^{71}$ He argues even that the Supreme Court would recognize the existence of a convention against their use: "with its recent willingness to deal with conventional questions touching on 'constitutionality and legitimacy,' the Supreme Court of Canada would now in all likelihood state that the powers of reservation and disallowance have been neutered by convention." ${ }^{\prime 2}$

Heard is not alone in believing the disallowance power has succumbed to a convention of non-use because of its illegitimacy. In his study of the Constitution of Canada, Jeremy Webber noted that some have suggested that there now exists a convention against their use and that "certainly there would be a constitutional crisis if they were used." " ${ }^{\text {s }}$ Andrew Banfield notes that using these powers has become "seen as increasingly illegitimate the point where a convention of non-use developed." ${ }^{\prime \prime 4}$ Many others have made similar assessments. ${ }^{75}$ In the Patriation Reference, a majority of justices declared that "reservation and disallowance of provincial legislation, although in law still open, have, to all intents and purposes, fallen into disuse." ${ }_{76}$ And earlier, as a judge on the Ontario Court of Appeal, the future

\footnotetext{
${ }^{7} \mathrm{Id}$. at 96 (Hudson J.).

"Andrew Heard, Canadian Constitutional Conventions: The Marriage of LAW AND POLITICS 103, 105 (1991).

"Id. at 105.

${ }^{73}$ Jeremy WebBer, The Constitution of CAnAda: A Contextual Analysis 136 (2015).

"Andrew C. Banfield, Canada, in CONSTITUtional CONVENTIONS IN WestMinster SYSTEMS 189, 191 (Brian Galligan \& Scott Brenton eds., 2015).

${ }^{75}$ See, e.g., RONAld J. ChefFins, The CONSTitutional Process IN CANAdA 11, 29, 82, 86 (1969); RONALD I. CHEFFINS \& PATRICIA A. JOHNSON, THE REVISED CANADIAN CONSTITUTION: POLITICS AS LAW 120 (1986); JENNIFER SMITH, FEDERALISM 55 (2011); NORMAN WARD, DAWSON'S THE GOVERNMENT OF CANADA 225 (6th ed. 1987); K.C. WHEARE, FEDERAL GOVERNMENT 18-21 (1946).

${ }^{76}$ Patriation Reference, supra note 8, at 802.
} 
Chief Justice of Canada wrote that both powers "are dormant if not entirely dead."

\section{B. Enforcing the Convention of Non-Use}

Imagine now that the Government of Canada exercised its disallowance power to repeal a law passed by the Alberta legislature and duly signed by the Lieutenant Governor. This is in no way inconceivable. In 2000, Alberta amended its provincial marriage Act to define marriage as a union between one man and one woman. ${ }^{78} \mathrm{At}$ the time, advocates for marriage equality were mounting their fight in Canada. Under pressure to make a decision on the constitutionality of different forms of union, the Government of Canada choose to initiate a reference to the Supreme Court of Canada on the marriage question, ${ }^{9}$ but it could well have decided to disallow Alberta's law instead.

Had the Government of Canada disallowed the law, Alberta would have challenged the disallowance on several grounds, one of which surely would have been that after decades of non-use, a convention preventing the Government of Canada from exercising the disallowance power had come into existence. The Government of Canada would have defended its disallowance of the Alberta law with reference to the Court's views that the rule of law "requires that courts give effect to the Constitution's text, and apply, by whatever its terms, legislation that conforms to that text."

The question before the Court would be how to treat the convention of non-use that had effectively repealed the disallowance power from the Constitution. The Court could draw from the existing toolkit of approaches to conventions that we modelled earlier. It could quarantine itself from all this question altogether, reasoning that the subject raises a question of convention, not of law, and that it is accordingly best resolved by political actors. The Court could alternatively act as bystander, refusing to engage the question involving the convention since doing so would be unnecessary to the resolution of the legal dispute, namely whether the Government of Canada has the legal authority to exercise the disallowance power. That the power is entrenched in the Constitution would be sufficient under the bystander approach for the Court to resolve the dispute with a definitive statement that there is no ground to deny the legal

" BORA LASKIN, THE BRITISH TRADITION IN CANADA LAW 121-22 (1969).

${ }^{78}$ Marriage Amendment Act, 2000, Statutes of Alberta 2000, ch. 3, ss. 4, 5.

"See Reference Re Same-Sex Marriage, 3 S.C.R. 698 (2004).

so British Columbia v. Imperial Tobacco Canada Ltd., 2 S.C.R. 473 at para. 67 (2005). 
validity of a textually entrenched power the Constitution has properly conferred to a constitutional actor.

Or the Court could assume the role of advisor, going further than a bystander court. Here, the Court would offer advice on the question concerning the existence of a convention on the non-use of the disallowance power. Alternatively, acting as guardian, the Court would seek to enforce the convention. It would justify doing so by reference to its role as the guardian of the constitution, and offer no other justification - legal or otherwise.

We believe that none of these three approaches is right. The approach we propose-that of an executor court enforcing the legitimate expectations of political actors as reflected in the convention of non-use of the disallowance power-strikes us as better.

What would an executor court do? Here, the issue is a powershifting convention that has shifted de facto power away from the Government of Canada to provincial governments. An executor court would enforce conventions to give effect to what constitutional actors regard as the legitimate allocation of power. Thus an executor court would enforce the convention in this case.

For reasons of comity, however, an executor court would craft the remedy, and enforce the convention, in the least intrusive way possible. A declaration of the existence of the convention, and of its breach by the Government, could well be treated as authoritative by Canadian political actors, both federal and provincial. The Government could conceivably commit to not disallow the same law, were it passed by Alberta's legislature again. The Court's decision to make a declaration offers all the advantages, but none of the pretense associated with advisor courts. The declaration facilitates the working of conventions by enhancing the certainty and stability with which they operate, and the court would not deny that the declaration was a form of enforcement.

But what if political conditions in Canada were different? Imagine the Government of Canada was unlikely to make any commitment not to exercise its disallowance power, or perhaps the Alberta legislature was not in a position to pass the law again. An executor court would resort to a more intrusive form of enforcement. It would invalidate the Government's exercise of the disallowance power as an extension of the doctrine of legitimate expectations. By its action, the executor court would be giving effect to the judgment of political actors developed over time-and expressed in the form of a constitutional conventionthat decisions under provincial heads of power are legitimately made by the provinces themselves.

\section{CONCLUSION}


Through an analysis of the many possible modes of judicial engagement with conventions, and a study of an array of roles courts could inhabit, we argued that Commonwealth courts are sometimes justified in not just recognizing and employing, but also enforcing conventions. Quarantined courts are impractical; bystander courts fail to facilitate the working of conventions; advisor courts are unstable; and guardian courts are unable to answer familiar objections to enforcing conventions. It is our view that courts should - contra the quarantined role - recognize and employ conventions. More controversially - contra the bystander, advisor and guardian role courts should enforce constitutional conventions, though only those conventions that shift power between constitutional actors.

The limitations of our claim about how courts should treat conventions must be emphasized. Courts should not enforce all conventions - only a limited class of them. When they enforce conventions, courts should do so in the least intrusive way. Since a judicial declaration is often all that is necessary for enforcement, it might in some cases be all that is justified. Some will worry that our arguments expand judicial power. But what we propose also constrains its exercise. After the Patriation Reference, the idea that courts may make declarations about what any constitutional convention requires has taken hold in some Commonwealth courts. We argue in our earlier Article in this journal ${ }^{\text {st }}$ that such declarations often are a type of judicial enforcement; we argue in this Article that enforcement is justified for only a limited class of conventions.

To these limitations, we will add a word of caution for courts. All judicial engagement with constitutional conventions - recognition, employment and enforcement - should avoid inhibiting the inherent and constitutive flexibility and adaptiveness of conventions. Judicial engagement with conventions are like photographs of a moving target. Such photographs may be authoritative for some purposes for instance to determine who crossed the finish line first at a race. But it would be a mistake to treat the photograph as a true account of where the contestants are located ten minutes later. It is important that judges and political actors understand that changed conditions, including their own changed behavior, can change conventions. Otherwise the virtues of regulation by convention rather than law participation, flexibility, effectiveness - may be lost.

Our proposal for a new judicial role - an executor court - is inspired by our study of three Commonwealth jurisdictions where courts have self-consciously recognized, employed and in some cases

${ }^{s}$ Ahmed, Albert and Perry, supra note 1.. 
enforced constitutional conventions. We are comfortable recommending as a matter of institutional practice that courts in Canada, India and the UK ought to play the role of executor courts where appropriate, under the conditions we have outlined.

The court as executor could conceivably take root elsewhere, even outside of the Commonwealth, but certainly within it. Consider the caretaker convention as applied in New Zealand, which requires a defeated government to constrain its official conduct until a new ministry is appointed after the transition period of government formation. ${ }^{82}$ Imagine the defeated government indicated its intention to refuse to execute decisions properly made by the incoming, but not yet sworn-in government. New Zealand offers us a case study in this type of conflict: in 1984, Prime Minister Robert Muldoon lost a general election yet refused to follow the urgent advice of the Reserve Bank and the incoming government on a currency crisis that threatened to devalue the national dollar in short order. ${ }^{83}$ Viewing himself as the rightful decisionmaker insofar as he remained prime minister during the transition period, Muldoon suggested that he would not relent for the remainder of his term, which was to end ten days later when the new government would be sworn in after the return of the writs. ${ }^{84}$ Muldoon eventually succumbed to pressure from his party colleagues, but had he insisted on defying the caretaker convention, an executor court would have been justified in enforcing the convention, as an expression of constitutional actors' judgment on the legitimate allocation of power.

Our prescriptions relating to the enforcement of power-shifting constitutional conventions may therefore have significance not just in the United Kingdom, Canada and India, but beyond as well.

¿2ABinet OfFice, CABINet MANUAL 90 (2017).

"Jonathan Boston et al., Caretaker Government and the Evolution of Caretaker Conventions in New Zealand, 28 ViCTORIA U. WELLINGTON L. REV. 629, 635 (1998).

st Id. 